\title{
How to ventilate preterm infants with lung compliance close to circuit compliance: real-time simulations on an infant hybrid respiratory simulator
}

\author{
Barbara Stankiewicz $^{1}$ D $\cdot$ Krzysztof J. Pałko $^{1} \cdot$ Marek Darowski $^{1} \cdot$ Maciej Kozarski $^{1}$
}

Received: 30 January 2019 / Accepted: 25 November 2019 / Published online: 18 December 2019

(C) International Federation for Medical and Biological Engineering 2019

\begin{abstract}
Circuit compliance close to lung compliance can create serious problems in effective and safe mechanical ventilation of preterm infants. We considered what ventilation technique is the most beneficial in this case. A hybrid (numerical-physical) simulator of infant respiratory system mechanics, the Bennett Ventilator and NICO apparatus were used to simulate pressure-controlled ventilation $(\mathrm{PC})$ and volume-controlled ventilation with constant flow $\left(\mathrm{VCV}_{\mathrm{CF}}\right)$ and descending flow $\left(\mathrm{VCV}_{\mathrm{DF}}\right)$, under permissive hypercapnia (PHC) $\left(6 \mathrm{ml} \mathrm{kg}^{-1}\right)$ and normocapnia (SV) $\left(8 \mathrm{ml} \mathrm{kg}^{-1}\right)$ conditions. Respiratory rate (RR) was 36 or $48 \mathrm{~min}^{-1}$ and PEEP was 0.3 or $0.6 \mathrm{kPa}$. Peak inspiratory pressure (PIP), mean airway pressure (MAP), and work of breathing by the ventilator (WOB) were lower $(P<0.01,1-\beta=0.9)$ using the PHC strategy compared to the SV strategy. The WOB increased $(P<0.01 ; 1$ $-\beta=0.9)$ when the RR increased. The PC, $\mathrm{VCV}_{\mathrm{CF}}$, and $\mathrm{VCV}_{\mathrm{DF}}$ modes did not differ in minute ventilation produced by the ventilator $\left(\mathrm{MV}_{\mathrm{V}}\right)$, but the $\mathrm{PC}$ mode delivered the highest minute ventilation to the patient $\left(\mathrm{MV}_{\mathrm{T}}\right)(P<0.01 ; 1-\beta=0.9)$ at the same PIP, MAP, and WOB. The most beneficial ventilation technique appeared to be PC ventilation with the PHC strategy, with lower RR $\left(36 \mathrm{~min}^{-1}\right)$.
\end{abstract}

Keywords Infant $\cdot$ Conventional mechanical ventilation $\cdot$ Permissive hypercapnia $\cdot$ Circuit compliance

\begin{tabular}{|c|c|c|c|}
\hline \multicolumn{2}{|c|}{ Abbreviations } & $F_{m}$ & Flow at the input of the numerical \\
\hline $1-\beta$ & test power & & model of patient respiratory system $\left(1 \mathrm{~s}^{-1}\right)$ \\
\hline BPD & Bronchopulmonary dysplasia & I:E & Inspiration to expiration ratio \\
\hline $\mathrm{C}_{\mathrm{dyn}}$ & $\begin{array}{l}\text { Total dynamic compliance (patient }+ \\
\text { ventilator circuit })\left(\mathrm{ml} \mathrm{kPa}^{-1}\right)\end{array}$ & $\mathrm{L}$ & $\begin{array}{l}\text { Inertance of patient respiratory } \\
\text { system }\left(\mathrm{kPa} \mathrm{s}^{2} \mathrm{l}^{-1}\right)\end{array}$ \\
\hline $\mathrm{CI}$ & Confidence interval & MAP & Mean airway pressure $(\mathrm{kPa})$ \\
\hline \multirow[t]{2}{*}{$\mathrm{C}_{\mathrm{L}}$} & Compliance of patient respiratory & $\mathrm{MV}_{\mathrm{T}}$ & Minute ventilation delivered do patient airways (l) \\
\hline & system $\left(\mathrm{ml} \mathrm{kPa}^{-1}\right)$ & $\mathrm{MV}_{\mathrm{V}}$ & Minute ventilation produced by ventilator (l) \\
\hline $\mathrm{C}_{\mathrm{V}}$ & Ventilator circuit compliance $\left(\mathrm{ml} \mathrm{kPa}^{-1}\right)$ & $\mathrm{P}$ & Pressure at input of TR $(\mathrm{kPa})$ \\
\hline ELBW & $\begin{array}{l}\text { A group of extremely low birth } \\
\text { weight preterm infants }\end{array}$ & $\mathrm{P}<\ldots$ & $\begin{array}{l}\text { Level of significance of the difference } \\
\text { between groups }\end{array}$ \\
\hline \multirow{3}{*}{$\begin{array}{l}f \\
F\end{array}$} & Breath frequency $\left(\mathrm{min}^{-1}\right)$ & $\mathrm{P}_{\mathrm{a}} \mathrm{CO}_{2}$ & Arterial partial pressure of carbon dioxide \\
\hline & Flow at the input of TR $\left(1 \mathrm{~s}^{-1}\right)$ & & $(\mathrm{mmHg}, \mathrm{kPa})$ \\
\hline & & $\mathrm{P}_{\mathrm{et}} \mathrm{CO}_{2}$ & $\begin{array}{l}\text { Partial pressure of carbon dioxide at the end of } \\
\text { exhalation }(\mathrm{mmHg}, \mathrm{kPa})\end{array}$ \\
\hline \multirow{2}{*}{$\begin{array}{ll}\mathrm{B} \\
\mathrm{b}\end{array}$} & Stankiewicz & $\mathrm{P}_{\mathrm{m}}$ & $\begin{array}{l}\text { Pressure at the input of the numerical model of the } \\
\text { patient respiratory system }(\mathrm{kPa})\end{array}$ \\
\hline & wicz@ ibib.waw.pl & $P_{\text {peak }}$ & Limit peak pressure set on the ventilator $(\mathrm{kPa})$ \\
\hline & ent of Modeling and Supporting of Internal Organs & $\mathrm{pH}$ & $\begin{array}{l}\text { Negative logarithm of hydrogen ion } \\
\text { concentration }\left(\mathrm{H}^{+}\right)\end{array}$ \\
\hline & $\begin{array}{l}\text { s, Nalecz Institute of Biocybernetics and Biomedical } \\
\text { ing Polish Academy of Sciences. 4 Troidena Street }\end{array}$ & PCV, PC & Pressure-controlled ventilation \\
\hline & $\begin{array}{l}\text { Poland } \\
\text { Pation, }\end{array}$ & $\mathrm{R}$ & Total airway resistance of patient $\left(\mathrm{kPa} \mathrm{s}^{-1}\right)$ \\
\hline
\end{tabular}


PHC Permissive hypercapnia, a strategy of ventilation with tidal volume 4-6 ml per $\mathrm{kg}$ of body mass

\begin{tabular}{|c|c|}
\hline PEEP & Positive end-expiratory pressure (kPa) \\
\hline PIP & Peak inspiratory pressure $(\mathrm{kPa})$ \\
\hline $\mathrm{R}_{\mathrm{e}}$ & $\begin{array}{l}\text { Total expiratory airway resistance of } \\
\text { patient }\left(\mathrm{kPa} \mathrm{s}^{-1}\right)\end{array}$ \\
\hline $\mathrm{R}_{\mathrm{i}}$ & $\begin{array}{l}\text { Total inspiratory airway resistance of } \\
\text { patient }\left(\mathrm{kPa} \mathrm{s}^{-1}\right)\end{array}$ \\
\hline RR & Respiratory rate $\left(\min ^{-1}\right)$ \\
\hline SD & Standard deviation \\
\hline SV & $\begin{array}{l}\text { Standard strategy of infant ventilation } \\
\text { with tidal volume } 8-10 \mathrm{ml} \text { per } \mathrm{kg} \text { of } \\
\text { body mass }\end{array}$ \\
\hline TR & Impedance transformer \\
\hline VCV & Volume-controlled ventilation \\
\hline $\mathrm{VCV}_{\mathrm{CF}}$ & $\begin{array}{l}\text { Volume-controlled ventilation with } \\
\text { constant flow pattern }\end{array}$ \\
\hline $\mathrm{VCV}_{\mathrm{DF}}$ & $\begin{array}{l}\text { Volume-controlled ventilation with } \\
\text { descending flow pattern }\end{array}$ \\
\hline WOB & Total work of breathing by the ventilator $\left(\mathrm{J}^{-1}\right)$ \\
\hline $\mathrm{Z}$ & Input impedance of the simulator $\left(\mathrm{kPa} \mathrm{s}^{-1}\right)$ \\
\hline $\mathrm{Z}_{\mathrm{m}}$ & $\begin{array}{l}\text { Impedance of the numeric part of the } \\
\text { simulator }\left(\mathrm{kPa} \mathrm{s}^{-1}\right)\end{array}$ \\
\hline$Z_{x}$ & $\begin{array}{l}\text { Impedance of pneumatic capacitor } \\
\text { representing gas compliance in piston } \\
\text { chamber of TR }\end{array}$ \\
\hline
\end{tabular}

\section{Introduction}

Lung protective ventilation, reducing barotrauma, ventilator-induced lung injury (VILI), and bronchopulmonary dysplasia (BPD) are key issues in modern respiratory therapy of preterm infants $[1,5,7]$. Barotrauma is lung tissue damage caused when the pressure provided to patient's airway is too high. By VILI, we mean volume injury to the lungs leading to morphological and physiological lung changes [6]. Bronchopulmonary dysplasia (BPD) is a common chronic lung disease of preterm infants which develops as a consequence of mechanical ventilation and oxygen therapy influencing immature lungs [22], causing airway remodeling, fibrosis, bronchial epithelium hyperplasia, lung field heterogeneity, and abnormal lung maturation $[8,19,29]$.

Permissive hypercapnia (PHC) is gaining ground in the ongoing discussion of infant lung protective ventilation. The strategy consists in keeping the $\mathrm{CO}_{2}$ arterial partial pressure higher than normal (i.e., $\mathrm{P}_{\mathrm{a}} \mathrm{CO}_{2}>40 \mathrm{mmHg}(5.3$ $\mathrm{kPa})$ ). It is applied to decrease the risk of VILI and chronic lung diseases [6, 21, 27]. It may protect against hypocapnia-induced brain hypoperfusion and subsequent periventricular leukomalacia and improve patient outcome
[23], e.g., of infants with congenital diaphragmatic hernia $(\mathrm{CDH})[10]$. According to a survey carried out in the USA a few years ago, $97 \%$ of neonatologists (of the 747 surveyed) were using $\mathrm{PHC}$ in their clinical practice [21]. Although PHC has clinical utility, caution must be taken to keep $\mathrm{PaCO}_{2}$ in the safe range: $45-55 \mathrm{mmHg}(6-7.3 \mathrm{kPa})$ on the first day of infant life and 55-65 $\mathrm{mmHg}(7.3-8.7$ $\mathrm{kPa}$ ) thereafter. Elevated $\mathrm{PaCO}_{2}$ levels cause an increased risk of intracranial hemorrhage $[28,30]$. PHC may also worsen white matter development in extremely low birth weight preterm infants (ELBW) [23]. Because of this risk, there is no general recommendation to use $\mathrm{PHC}$ in preterm infants [27]. However, the association between BPD, barotrauma, and volutrauma led to the use of PHC as a therapy to minimize lung injury [8] in preterm infants.

As a primary step in ventilation therapy of preterm infants, pressure-controlled ventilation (PCV) or highfrequency ventilation (HFV) is usually recommended [1, $12,14]$. Until recently, the use of volume-controlled ventilation (VCV) in preterm infants was a controversial issue, due to poor accuracy - a discrepancy between the volume of air reaching the patient's lungs $\left(V_{\mathrm{T}}\right)$ and the volume generated by the ventilator $\left(V_{\mathrm{V}}\right)$ (Eq. 1) [9]. The discrepancy is due to circuit compliance $\left(C_{\mathrm{V}}\right)$ creating dead space in the breathing circuit $\left(V_{\mathrm{DC}}\right)$ and tidal volume being determined from flow measured close to the expiratory valve (in-ventilator) [9, 18]. However, only the most modern ventilators determine tidal volume from flow measured at patient airways [18].

$\left\{\begin{array}{c}V_{\mathrm{T}}=V_{V}-V_{\mathrm{DC}} \\ V_{\mathrm{DC}}=C_{\mathrm{V}}(\mathrm{PIP}-\mathrm{PEEP})\end{array}\right.$

by multiplying both sides of the equations by breath frequency (f), we obtain:

$\left\{\begin{array}{c}\mathrm{MV}_{\mathrm{T}}=\mathrm{MV}_{\mathrm{V}}-\mathrm{MV}_{\mathrm{DC}} \\ \mathrm{MV}_{\mathrm{DC}}=f C_{\mathrm{V}}(\mathrm{PIP}-\mathrm{PEEP})\end{array}\right.$

where $V_{\mathrm{T}}$ and $\mathrm{MV}_{\mathrm{T}}$ are the tidal volume and minute ventilation, respectively, that reach patient airways; $V_{\mathrm{V}}$ and $\mathrm{MV}_{\mathrm{V}}$ are the volume and minute ventilation delivered by the ventilator; $V_{\mathrm{DC}}$ and $\mathrm{MV}_{\mathrm{DC}}$ are the dead volume and ventilation of the ventilator circuit; $C_{\mathrm{V}}$ is the ventilator circuit compliance; PIP is the peak inspiratory pressure; and PEEP is the positive end-expiratory pressure.

Ventilation of preterm infants, regardless of mode, is particularly difficult when infant lung compliance $\left(C_{\mathrm{L}}\right)$ is comparable to circuit compliance $\left(C_{\mathrm{V}}\right)$. Such a specific situation $\left(C_{\mathrm{L}} \approx C_{\mathrm{V}}\right)$ occurs in the patient group [17] examined in this study and, of course, can occur in others, e.g., in preterm infants with BPD [1]. In consequence, delivery of the desired tidal volume $\left(V_{\mathrm{T}}\right)$ to the lungs requires a 
significantly larger volume produced by the ventilator $\left(V_{\mathrm{V}}\right)$.

This study explored how to deal with the problem of circuit compliance when the newest type of neonatal ventilator (measuring circuit compliance at patient airways) is unavailable. Pressure-controlled ventilation was compared to volumecontrolled ventilation under permissive hypercapnia and normocapnia conditions, to assess any differences between the modes and strategies influencing patient's ventilation parameters - PIP (peak inspiratory pressure), MAP (mean airway pressure), PIF (peak inspiratory flow), PEF (peak expiratory flow), $C_{\mathrm{dyn}}$ (total dynamic compliance of respiratory system), $R_{\mathrm{i}}$ (total inspiratory airway resistance), $R_{\mathrm{e}}$ (total expiratory airway resistance), and WOB (work of breathing by ventilator) - and to find the best method and strategy to achieve minute ventilation $\left(\mathrm{MV}_{\mathrm{T}}\right)$ required by patients, minimizing MAP, PIP, and WOB, and thereby decreasing the risk of VILI [15].

The study tests were carried out using an infant respiratory simulator. This kind of study in the group of extremely low birth weight preterm infants, probably, would not be accepted by any ethical committee.

\section{Methods}

\subsection{The infant respiratory simulator}

The new infant hybrid respiratory simulator (Fig. 1) used in this study was described in detail in [26]. It is divided into two parts: numerical and physical. LabVIEW real-time software coordinates the work of the numerical and physical parts of the simulator and the interaction between the simulator and a ventilator. In this study, the numerical part of the simulator consisted of a three element (RLC) model of respiratory system mechanics, described by the inertance of central airways $(L)$, total airway resistance $(R)$, and lung compliance $(C)$. The physical part of the simulator consisted of an impedance transformer (TR) of the piston-cylinder design, which converts numeric signals of pressure and gas flow $\left(P_{\mathrm{m}}, F_{\mathrm{m}}\right)$, from the output of the numerical model of the respiratory system into real physical signals of pressure and flow $(P, F)$ at the input of TR. The impedance transformer function is described by the following set of equations (Eq. 3):
Fig. 1 The setup used in the study: infant hybrid respiratory simulator (IHRS), ventilator, and NICO monitor connected to a tablet computer. The IHRS is composed of a real-time computer with a numerical model of the lungs, implemented in LabVIEW software, impedance transformer (TR), host personal computer with operator interface communicating via TCP/IP protocol with $z$ real-time computer. PXI, personal computer-based platform of measurement and control systems; lung model: $L$, respiratory system inertance; $R$, total airway resistance; $C_{\mathrm{L}}$, total respiratory system compliance; $C_{\mathrm{V}}$, ventilator circuit compliance; $P_{\mathrm{m}}, F_{\mathrm{m}}$, pressure and flow in the input of the lung model, respectively; $P, F$, pressure and flow in the input of TR, respectively; DA, digital-to-analog converter; $\mathrm{AD}$, analog-to-digital converter
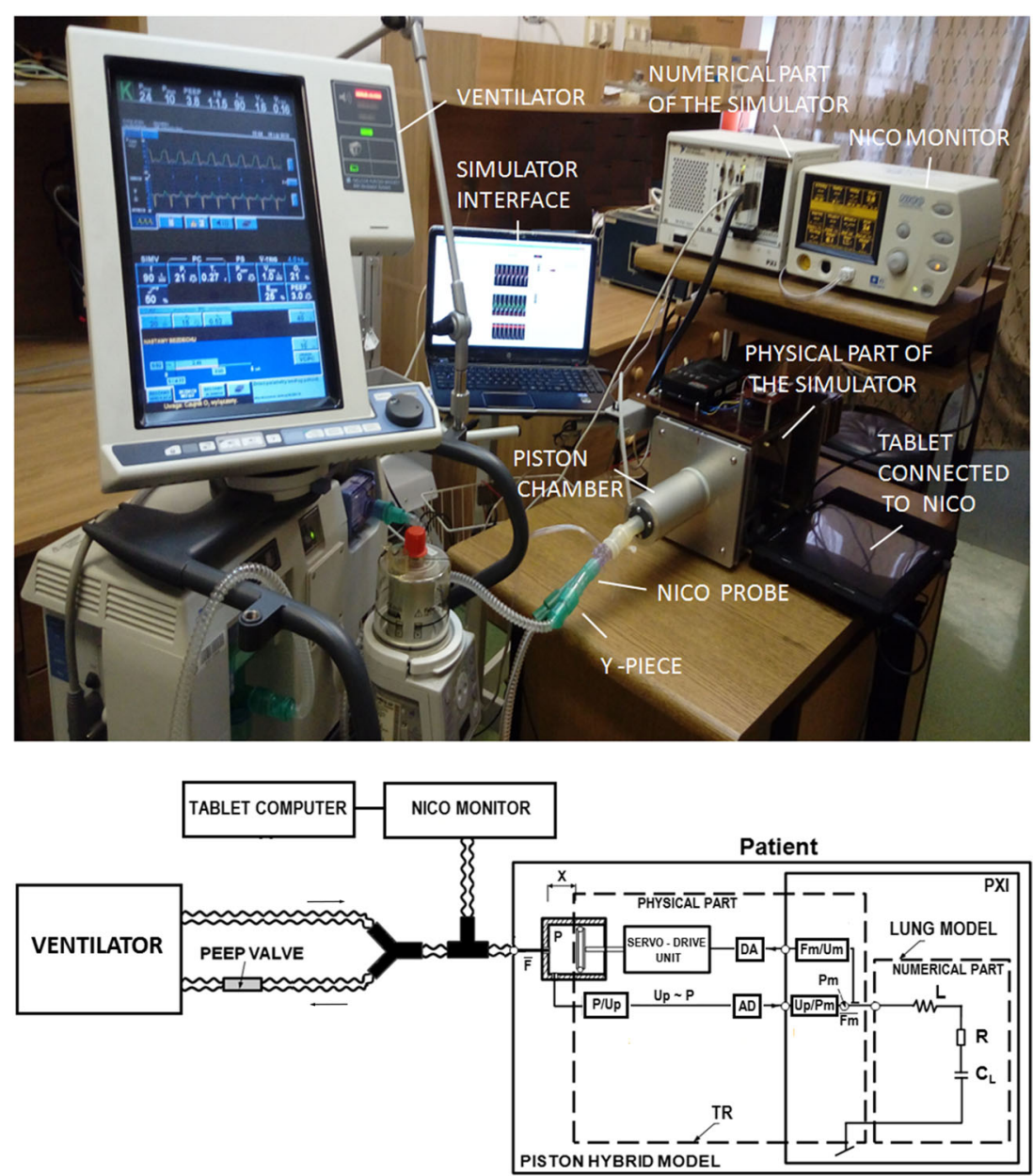


$$
\begin{aligned}
& Z=\frac{K Z_{\mathrm{m}} Z_{\mathrm{x}}}{K Z_{\mathrm{m}}+Z_{\mathrm{x}}} \\
& Z=\frac{P}{F} \\
& \left\{\begin{array}{l}
Z=\frac{P_{\mathrm{m}}}{F_{\mathrm{m}}} \\
Z_{\mathrm{m}}=\sqrt{X^{2}+R^{2}}
\end{array}\right. \\
& X=\omega L-\frac{1}{\omega c_{\mathrm{L}}} \\
& \omega=2 \pi f
\end{aligned}
$$

where $K$ is a constant value, $\omega$ is angular frequency, $f$ is breath frequency, $Z$ is the input impedance of the simulator, $Z_{\mathrm{m}}$ is the impedance of the numeric model of infant respiratory system, $X$ and $R$ are the imaginary and real (respectively) parts of the $Z_{\mathrm{m}}$ impedance, and $Z_{\mathrm{x}}$ is the impedance of the pneumatic capacitor representing gas compliance in the piston chamber. The compliance is a function of chamber volume, atmospheric pressure, and polytropic index $(n=1.3 \pm 0.5)$. Total error of impedance transformation $<2.5 \%$.

\subsection{Tests}

The tests were carried out using a setup (Fig. 1) consisting of the infant hybrid numerical-physical respiratory simulator [26], the Puritan Bennett 840 Ventilator (Medtronic, Fridley, MN, USA), and a NICO 7300 monitor (Respironics Corp., Murrysville, PA, USA) fitted with a main stream sensor, neonatal flow adapter, and a probe placed between the simulator and the Y-piece of the ventilation circuit. Ventilator settings for the ventilation of an "artificial" preterm infant representing the clinical group of patients (Table 1) are shown in Table 2.

Data were obtained for pressure-controlled ventilation and volume-controlled ventilation with constant and descending

Table 1 The characteristics of the patient group

\begin{tabular}{ll}
\hline Data & ELBW \\
\hline Age (test) & $5 \pm 2$ (days) \\
Gestation (weeks) & $27.2 \pm 1.2$ \\
Weigh (kg) & $0.820 \pm 0.107$ \\
Number of patients & 21 \\
ID ETT (mm) & 2.5 \\
$R\left(\mathrm{kPa} \mathrm{s} \mathrm{l}^{-1}\right)$ & $26.9 \pm 5.6$ \\
$C_{\mathrm{L}}\left(\mathrm{ml} \mathrm{kPa}^{-1}\right)$ & $8.6 \pm 5$ \\
$L\left(\mathrm{kPa} \mathrm{s}^{2} \mathrm{l}^{-1}\right)$ & 0.002 \\
\hline
\end{tabular}

The data are mean \pm SD

$E L B W$, extremely low birth weight infants; ID ETT, internal diameter of endotracheal tube; $R$, total (patient + ETT) respiratory system resistance; $C_{\mathrm{L}}$, respiratory system compliance; $L$, inertance of respiratory system; $S D$, standard deviation flow, under permissive hypercapnia (PHC) $\left(6 \mathrm{ml} \mathrm{kg}^{-1}\right)$ and normocapnia (SV) $\left(8 \mathrm{ml} \mathrm{kg}^{-1}\right)$ conditions for two sets of respiratory rates (RR) (36 and $48 \mathrm{~min}^{-1}$ ) and two sets of PEEP ( 0.3 and $0.6 \mathrm{kPa}$ ). The $\mathrm{MV}_{\mathrm{V}}$ was calculated by the ventilator and displayed on the ventilator monitor, whereas $\mathrm{MV}_{\mathrm{T}}, \mathrm{PIP}$, MAP, PIF, PEF, WOB, $C_{\text {dyn }}, R_{\mathrm{i}}$, and $R_{\mathrm{e}}$ were collected by the NICO 7300 monitor connected to a tablet computer.

\subsection{Statistical analysis}

First, the Shapiro-Wilk normality test and the Levene test of variance homogeneity were carried out. The study results were then analyzed by parametric and nonparametric tests. The parametric tests used were two-way ANOVA/ MANOVA tests, and the nonparametric tests were the Kruskal-Wallis analysis of ranks and Wilcoxon's test.

\section{Results}

The influence of the simulations' input parameters (MODE, STRATEGY, RR, and PEEP), which were set on the ventilator, on the output parameters (PIP, MAP, PIF, PEF, $C_{\mathrm{dyn}}, R_{\mathrm{i}}, R_{\mathrm{e}}$, and WOB) was measured using the NICO monitor at the "patient" airway. The results are presented in Figs. 2, 3, 4, 5, 6, 7, and 8.

In the experiment, the three modes of ventilation were set: pressure-controlled ventilation, volume-controlled ventilation mode with constant flow, and volume-controlled ventilation with descending flow. During pressure-controlled ventilation, we adjusted the peak pressure $\left(P_{\text {peak }}\right)$ to indirectly achieve the same minute ventilation $\left(\mathrm{MV}_{\mathrm{V}}=f \mathrm{~V}_{\mathrm{V}}\right)$ delivered by the ventilator with volume-controlled modes, where it was set directly. This kept the $M V_{V}$ value constant for all experimental tests within a given STRATEGY, but different for permissive hypercapnia and normocapnia ventilation.

Generally, the influence of the ventilation mode (PCV, $\mathrm{VCV}_{\mathrm{CF}}$, and $\mathrm{VCV}_{\mathrm{DF}}$ ) on the patient's ventilation parameters was statistically significant $(P<0.01,1-\beta=0.99)$. Specifically, significant differences between these modes were observed for the PIF, PEF, $R_{\mathrm{i}}$, and $R_{\mathrm{e}}$ parameters, whereas the levels of PIP, MAP, and WOB did not differ statistically between modes (Fig. 2).

Permissive hypercapnia and normocapnia, which were accomplished by setting the tidal volume delivered to the patient ( 6 or $8 \mathrm{ml} \mathrm{kg}^{-1}$, respectively), significantly influenced the output ventilation parameters $(P<0.01,1-\beta=0.99)$ (Fig. 3$)$. The values of PIP, PIF, PEF, and WOB measured under permissive hypercapnia $\left(6 \mathrm{ml} \mathrm{kg}^{-1}\right)$ were significantly lower than under normocapnia $\left(8 \mathrm{ml} \cdot \mathrm{kg}^{-1}\right)$. There was no difference between the two strategies in MAP, dynamic compliance of the respiratory system $\left(C_{\mathrm{dyn}}\right)$, and dynamic airway resistances $\left(R_{\mathrm{i}}\right.$ and $R_{\mathrm{e}}$ ). For these values, the interaction between ventilation MODE and STRATEGY appeared to be insignificant (Fig. 4). 
Table 2 Ventilation parameters and Reynolds number for different study cases

\begin{tabular}{|c|c|c|c|c|c|c|c|c|c|c|c|c|}
\hline Mode & $P_{\text {peak }}(\mathrm{kPa})$ & $\begin{array}{l}\mathrm{RR} \\
\qquad \begin{array}{l}(\mathrm{mi}- \\
\left.\mathrm{n}^{-1}\right)\end{array}\end{array}$ & $\mathrm{I}: \mathrm{E}$ & $\begin{array}{l}\text { PEEP } \\
(\mathrm{kPa})\end{array}$ & $\begin{array}{l}\text { Strategy (ml } \\
\left.\qquad \mathrm{kg}^{-1}\right)\end{array}$ & $\begin{array}{r}\mathrm{MV}_{\mathrm{v}} \\
(1)\end{array}$ & $\begin{array}{l}\text { PIF } \\
\qquad\left(1 s^{-1}\right)\end{array}$ & $\begin{array}{l}\text { PEF } \\
\qquad\left(1 s^{-1}\right)\end{array}$ & $V_{\text {insp }}^{\cdot}(\mathrm{m}$ & $V_{\mathrm{exp}^{-1}}^{\cdot}(\mathrm{m}$ & $\begin{array}{l}\mathrm{Re}_{\text {(insp) }} \\
(-)\end{array}$ & $\begin{array}{r}\operatorname{Re}_{(\exp )} \\
\quad(-)\end{array}$ \\
\hline PCV & 0.8 & 36 & 01:01 & 0.3 & PH (6) & 0.18 & 0.012 & 0.036 & 0.123 & 0.123 & 89 & 89 \\
\hline $\mathrm{PCV}$ & 0.8 & 36 & 01:02 & 0.6 & PH (6) & 0.18 & 0.014 & 0.033 & 0.143 & 0.143 & 104 & 104 \\
\hline $\mathrm{PCV}$ & 0.8 & 36 & 01:01 & 0.3 & PH (6) & 0.18 & 0.012 & 0.039 & 0.123 & 0.123 & 89 & 89 \\
\hline $\mathrm{PCV}$ & 1 & 36 & 01:02 & 0.6 & PH (6) & 0.19 & 0.018 & 0.044 & 0.193 & 0.193 & 141 & 141 \\
\hline $\mathrm{PCV}$ & 1.1 & 48 & 01:01 & 0.3 & PH (6) & 0.24 & 0.023 & 0.045 & 0.242 & 0.242 & 176 & 176 \\
\hline PCV & 1.2 & 48 & 01:02 & 0.6 & PH (6) & 0.28 & 0.025 & 0.041 & 0.261 & 0.261 & 190 & 190 \\
\hline $\mathrm{PCV}$ & 1 & 48 & 01:01 & 0.3 & PH (6) & 0.23 & 0.017 & 0.042 & 0.174 & 0.174 & 127 & 127 \\
\hline $\mathrm{PCV}$ & 0.9 & 48 & 01:02 & 0.6 & PH (6) & 0.23 & 0.013 & 0.038 & 0.140 & 0.140 & 102 & 102 \\
\hline PCV & 1 & 36 & 01:01 & 0.3 & SV (8) & 0.26 & 0.018 & 0.051 & 0.193 & 0.193 & 141 & 141 \\
\hline $\mathrm{PCV}$ & 1 & 36 & 01:01 & 0.6 & SV (8) & 0.27 & 0.018 & 0.047 & 0.193 & 0.193 & 141 & 141 \\
\hline $\mathrm{PCV}$ & 1.1 & 36 & 01:02 & 0.3 & SV (8) & 0.26 & 0.027 & 0.052 & 0.283 & 0.283 & 206 & 206 \\
\hline $\mathrm{PCV}$ & 1.1 & 36 & 01:02 & 0.6 & SV (8) & 0.27 & 0.025 & 0.051 & 0.266 & 0.266 & 194 & 194 \\
\hline $\mathrm{PCV}$ & 1.1 & 48 & 01:01 & 0.3 & SV (8) & 0.31 & 0.013 & 0.042 & 0.141 & 0.141 & 103 & 103 \\
\hline $\mathrm{PCV}$ & 1.1 & 48 & 01:01 & 0.6 & SV (8) & 0.31 & 0.013 & 0.042 & 0.140 & 0.140 & 102 & 102 \\
\hline PCV & 1.3 & 48 & 01:02 & 0.3 & SV (8) & 0.32 & 0.020 & 0.045 & 0.214 & 0.214 & 156 & 156 \\
\hline $\mathrm{PCV}$ & 1.3 & 48 & 01:02 & 0.6 & SV (8) & 0.31 & 0.019 & 0.040 & 0.202 & 0.202 & 147 & 147 \\
\hline Mode & $F_{\max }\left(\min ^{-1}\right)$ & $\begin{array}{l}\text { RR } \\
\qquad \begin{array}{l}\left(\mathrm{mi}^{-}\right. \\
\left.\mathrm{n}^{-1}\right)\end{array}\end{array}$ & $\begin{array}{l}\text { PEEP } \\
(\mathrm{kPa})\end{array}$ & \multicolumn{2}{|c|}{ Strategy $\left(\mathrm{ml} \mathrm{kg}^{-1}\right)$} & $\begin{array}{r}\mathrm{MV}_{\mathrm{v}} \\
\text { (1) }\end{array}$ & $\begin{array}{r}\text { PIF (1 } \\
\left.s^{-1}\right)\end{array}$ & $\begin{array}{c}\mathrm{PEF}(1 \\
\left.\mathrm{s}^{-1}\right)\end{array}$ & $V_{\text {insp }}^{\cdot}(\mathrm{m}$ & $V_{\left.\mathrm{exp}^{-1}\right)}(\mathrm{m}$ & $\begin{array}{c}\operatorname{Re}_{\text {(insp) }} \\
\quad(-)\end{array}$ & $\begin{array}{r}\operatorname{Re}_{(\exp )} \\
\quad(-)\end{array}$ \\
\hline $\mathrm{VCV}_{\mathrm{CF}}$ & 2.3 & 36 & 0.3 & \multicolumn{2}{|l|}{ PH (6) } & 0.18 & 0.024 & 0.026 & 0.255 & 0.277 & 185 & 201 \\
\hline $\mathrm{VCV}_{\mathrm{CF}}$ & 2.3 & 36 & 0.6 & \multicolumn{2}{|l|}{ PH (6) } & 0.18 & 0.025 & 0.032 & 0.260 & 0.332 & 190 & 242 \\
\hline $\mathrm{VCV}_{\mathrm{CF}}$ & 2.1 & 48 & 0.6 & \multicolumn{2}{|l|}{ PH (6) } & 0.18 & 0.023 & 0.032 & 0.247 & 0.336 & 180 & 244 \\
\hline $\mathrm{VCV}_{\mathrm{CF}}$ & 2.1 & 48 & 0.3 & \multicolumn{2}{|l|}{$\mathrm{PH}(6)$} & 0.23 & 0.022 & 0.032 & 0.235 & 0.333 & 171 & 243 \\
\hline $\mathrm{VCV}_{\mathrm{CF}}$ & 2.7 & 48 & 0.3 & \multicolumn{2}{|l|}{ SV (8) } & 0.33 & 0.029 & 0.043 & 0.309 & 0.452 & 225 & 329 \\
\hline $\mathrm{VCV}_{\mathrm{CF}}$ & 2.7 & 48 & 0.6 & \multicolumn{2}{|l|}{ SV (8) } & 0.33 & 0.027 & 0.039 & 0.281 & 0.414 & 204 & 301 \\
\hline $\mathrm{VCV}_{\mathrm{CF}}$ & 2.8 & 36 & 0.6 & \multicolumn{2}{|l|}{ SV (8) } & 0.25 & 0.028 & 0.044 & 0.291 & 0.464 & 212 & 338 \\
\hline $\mathrm{VCV}_{\mathrm{CF}}$ & 2.8 & 36 & 0.3 & \multicolumn{2}{|c|}{ SV (8) } & 0.25 & 0.030 & 0.042 & 0.313 & 0.442 & 228 & 321 \\
\hline Mode & $\begin{array}{l}F_{\max }(1 \\
\left.\min ^{-1}\right)\end{array}$ & $\begin{array}{l}\text { RR } \\
\qquad \begin{array}{l}\left(\mathrm{mi}^{-}\right. \\
\left.\mathrm{n}^{-1}\right)\end{array}\end{array}$ & $\begin{array}{l}\text { PEEP } \\
(\mathrm{kPa})\end{array}$ & \multicolumn{2}{|c|}{ Strategy $\left(\mathrm{ml} \mathrm{kg}^{-1}\right)$} & $\begin{array}{r}\mathrm{MV}_{\mathrm{v}} \\
(1)\end{array}$ & $\begin{array}{c}\mathrm{PIF}(1 \\
\left.\mathrm{s}^{-1}\right)\end{array}$ & $\begin{array}{c}\mathrm{PEF}(1 \\
\left.\mathrm{s}^{-1}\right)\end{array}$ & $V_{\text {insp }}^{\cdot(m}$ & $\begin{array}{l}\dot{\mathrm{V}}_{\exp }(\mathrm{m} \\
\left.\mathrm{s}^{-1}\right)\end{array}$ & $\begin{array}{c}\operatorname{Re}_{\text {(insp) }} \\
\quad(-)\end{array}$ & $\begin{array}{r}R e_{(\exp )} \\
\quad(-)\end{array}$ \\
\hline $\mathrm{VCV}_{\mathrm{DF}}$ & 3.2 & 36 & 0.3 & \multicolumn{2}{|l|}{$\mathrm{PH}(6)$} & 0.18 & 0.022 & 0.026 & 0.231 & 0.274 & 168 & 200 \\
\hline $\mathrm{VCV}_{\mathrm{DF}}$ & 3.2 & 36 & 0.6 & \multicolumn{2}{|l|}{ PH (6) } & 0.19 & 0.023 & 0.028 & 0.241 & 0.294 & 175 & 214 \\
\hline $\mathrm{VCV}_{\mathrm{DF}}$ & 2.5 & 48 & 0.3 & \multicolumn{2}{|l|}{ PH (6) } & 0.22 & 0.018 & 0.027 & 0.193 & 0.280 & 141 & 204 \\
\hline $\mathrm{VCV}_{\mathrm{DF}}$ & 2.7 & 48 & 0.6 & \multicolumn{2}{|l|}{ PH (6) } & 0.23 & 0.020 & 0.026 & 0.210 & 0.275 & 153 & 200 \\
\hline $\mathrm{VCV}_{\mathrm{DF}}$ & 3.2 & 36 & 0.3 & \multicolumn{2}{|l|}{ SV (8) } & 0.23 & 0.025 & 0.038 & 0.263 & 0.402 & 191 & 293 \\
\hline $\mathrm{VCV}_{\mathrm{DF}}$ & 3.2 & 36 & 0.6 & \multicolumn{2}{|l|}{ SV (8) } & 0.24 & 0.024 & 0.038 & 0.252 & 0.404 & 183 & 294 \\
\hline $\mathrm{VCV}_{\mathrm{DF}}$ & 2.9 & 48 & 0.6 & \multicolumn{2}{|l|}{ SV (8) } & 0.32 & 0.022 & 0.038 & 0.228 & 0.403 & 166 & 293 \\
\hline $\mathrm{VCV}_{\mathrm{DF}}$ & 3 & 48 & 0.3 & \multicolumn{2}{|l|}{ SV (8) } & 0.32 & 0.023 & 0.037 & 0.246 & 0.386 & 179 & 281 \\
\hline
\end{tabular}

$P C V$, pressure-controlled mode of ventilation; $V C V_{C F}, V C V_{D F}$, volume-controlled mode of ventilation with constant and descending flow, respectively; $P_{P e a k}$, pressure limit; $R R$, respiratory rate; $I: E$, inspiration:expiration ratio; PEEP, positive end-expiratory pressure; STRATEGY, tidal volume per kilogram of body mass; $P H$, permissive hypercapnia $\left(6 \mathrm{ml} \mathrm{kg}^{-1}\right) ; S V$, standard ventilation $\left(8 \mathrm{ml} \mathrm{kg}^{-1}\right) ; M V_{V}$, minute ventilation set on the ventilator; $F_{\text {max }}$, flow limit set on the ventilator; $R e_{(i n s p)}, R e_{(\text {exp })}$, Reynold's number for inspiration and expiration, respectively; $P I F, P E F$, peak inspiratory flow and peak expiratory flow; $\dot{V}_{\text {insp }}, \dot{V}_{\text {exp }}$, mean linear velocity during inspiration and expiration, respectively

Next, the independent variable $\mathrm{RR}$ had a significant influence on the ventilation parameters $(P<0.05,1-\beta$ $=0.83$ ) (Fig. 5). However, the interaction of RR and MODE did not have a significant influence on these parameters (Fig. 6).
PEEP settings had a significant influence on the measured parameters of ventilation $(P<0.01,1-\beta=0.99)$, too (Fig. 7). However, the interaction of PEEP with any other parameter was not significant. Similarly, all other interactions between considered independent variables of ventilation (MODE, 

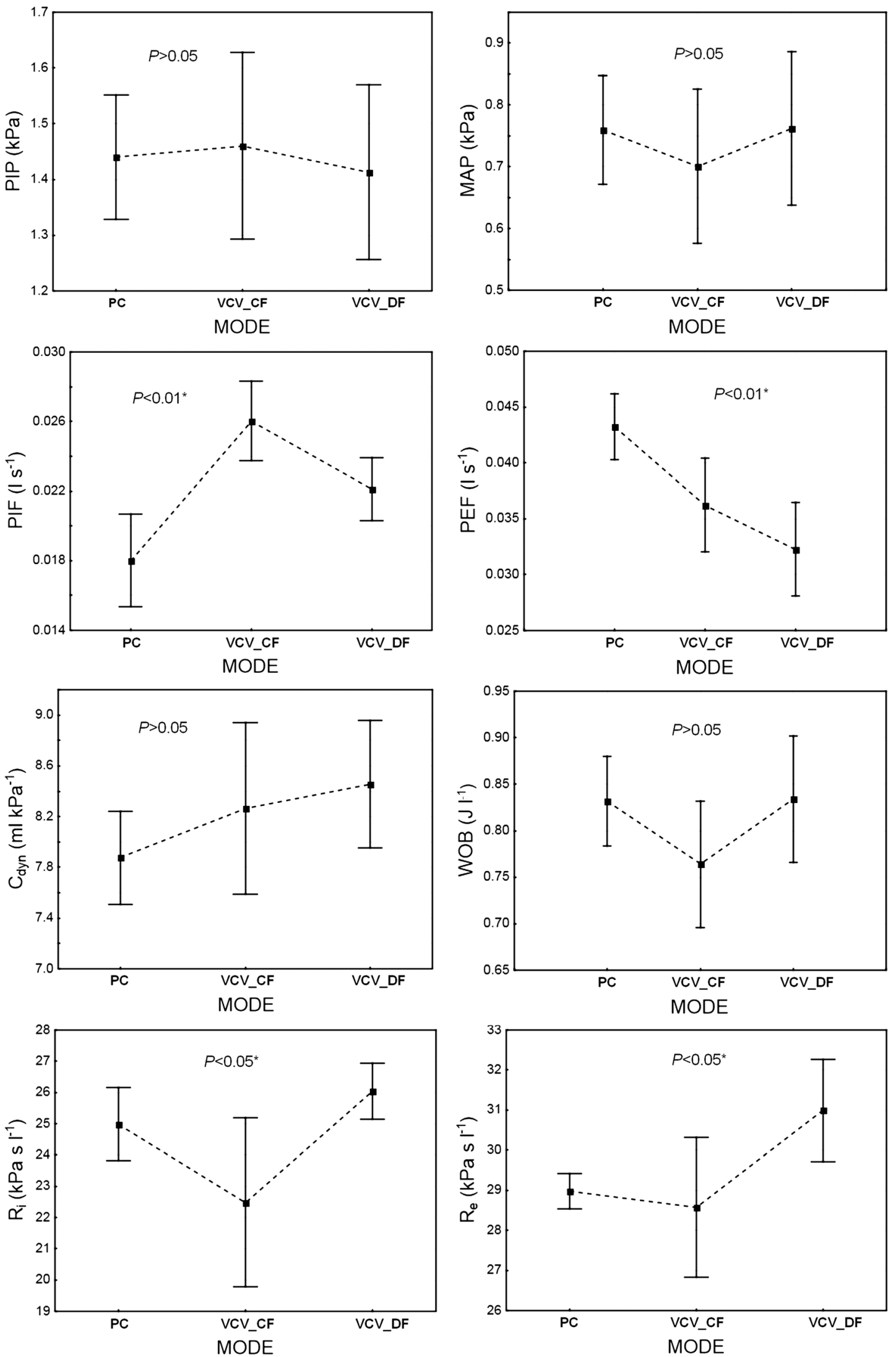

Fig. 2 The influence of ventilation $\mathrm{MODE}\left(\mathrm{PC}, \mathrm{VCV}_{\mathrm{CF}}, \mathrm{VCV}_{\mathrm{DF}}\right)$ on the infant's ventilation parameters: PIP, MAP, PIF, PEF, $C_{\mathrm{dyn}}, \mathrm{WOB}, R_{\mathrm{i}}$, and $R_{\mathrm{e}}(P<$ $0.01,1-\beta=0.99) . \mathrm{PC}=\mathrm{PCV}$. The data are mean $\pm 95 \% \mathrm{CI}$ 

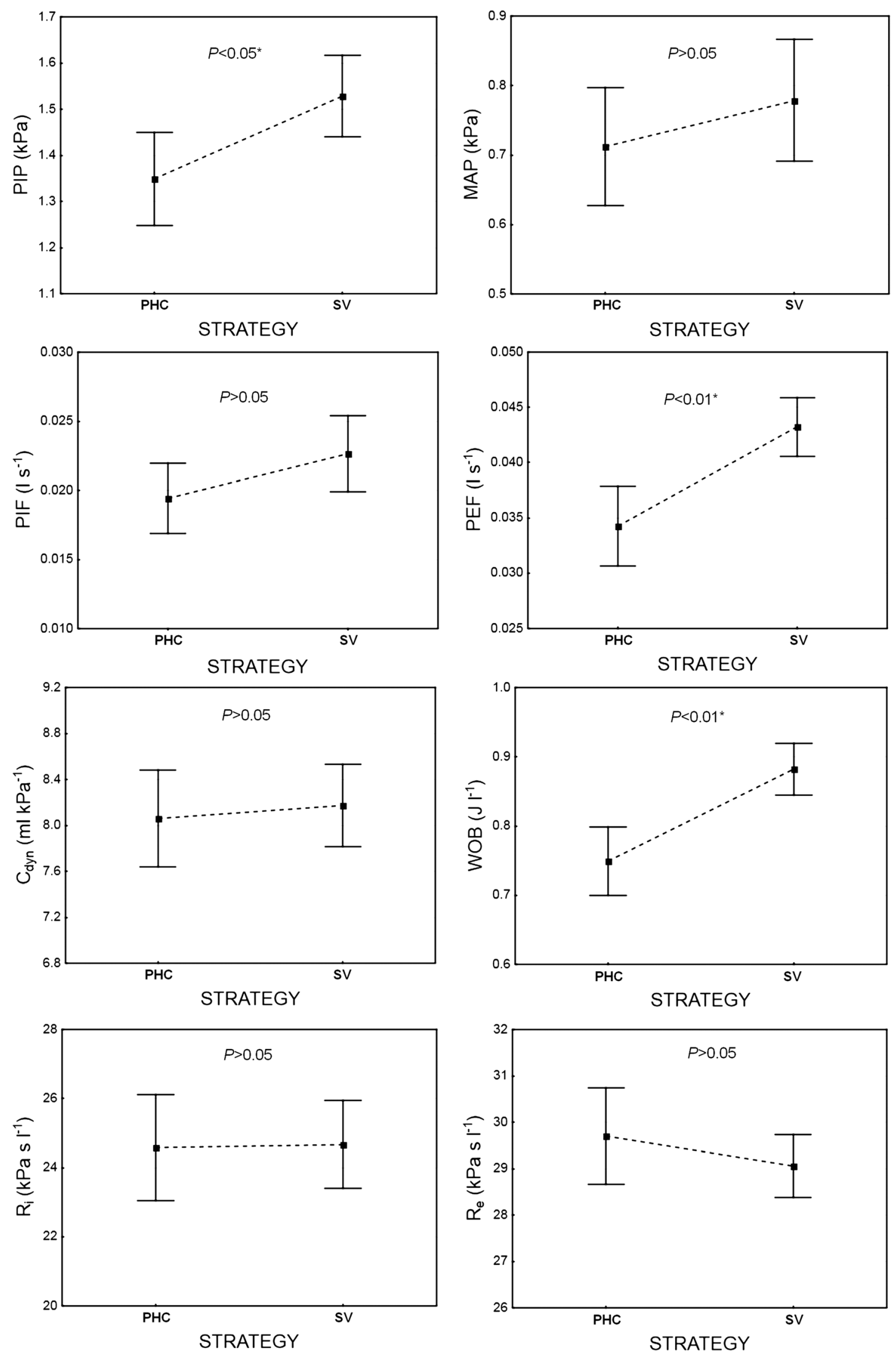

Fig. 3 The influence of ventilation STRATEGY - permissive hypercapnia (PHC) versus normocapnia (SV) on the infant's ventilation parameters: PIP, MAP, PIF, PEF, $C_{\mathrm{dyn}}, \mathrm{WOB}, R_{\mathrm{i}}$, and $R_{\mathrm{e}}(P<0.01,1-\beta=0.99)$. The data are mean $\pm 95 \% \mathrm{CI}$ 

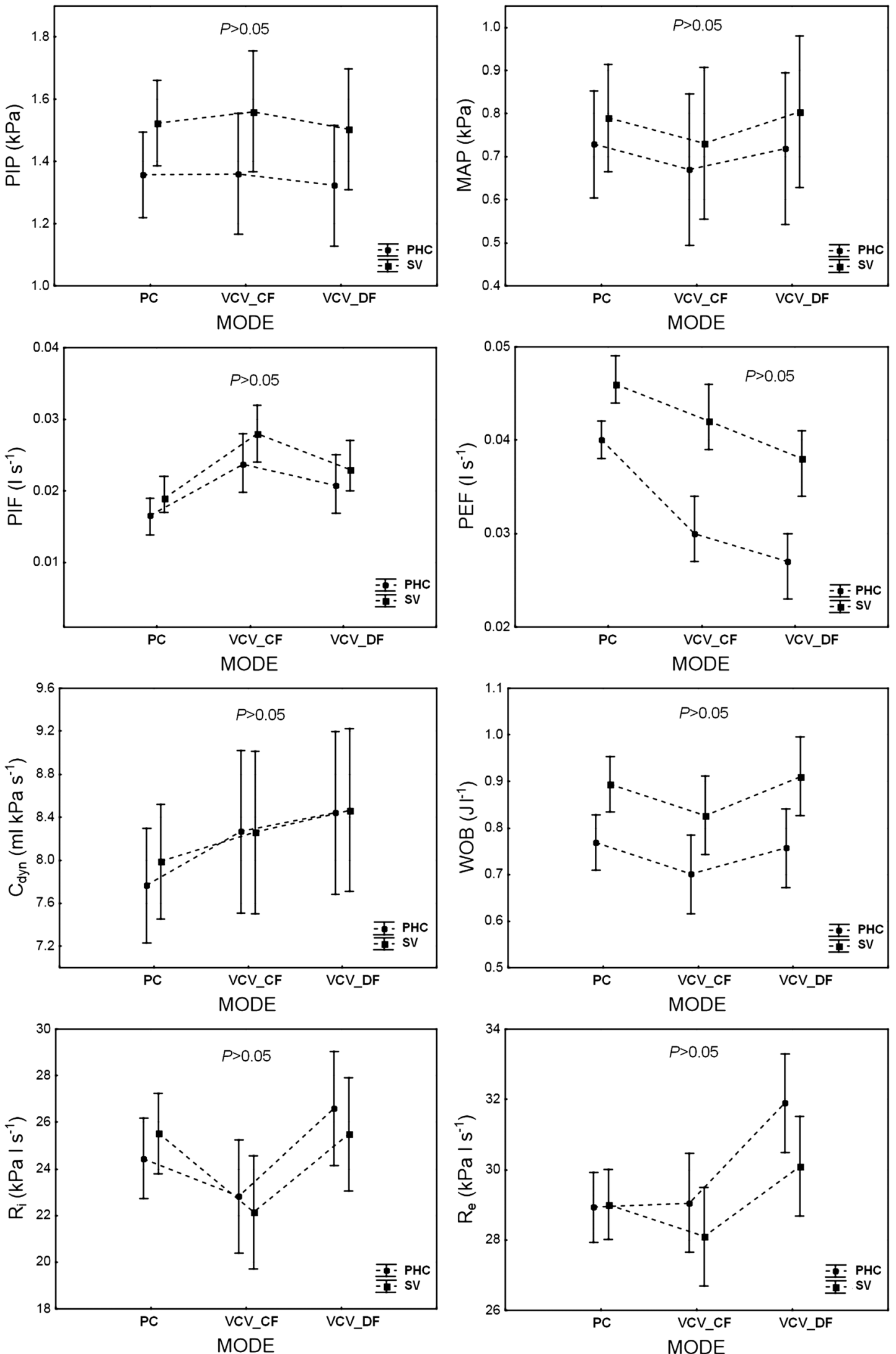

Fig. 4 The infant's ventilation parameters: PIP, MAP, PIF, PEF, $C_{\mathrm{dyn}}$, WOB, $R_{\mathrm{i}}$, and $R_{\mathrm{e}}$, depending on ventilation $\mathrm{MODE}\left(\mathrm{PC}, \mathrm{VCV} \mathrm{CF}_{\mathrm{DCV}}\right.$, VE) and ventilation STRATEGY - permissive hypercapnia $(\mathrm{PHC})$ versus normocapnia $(\mathrm{SV}) . \mathrm{PC}=\mathrm{PCV}$. The data are mean $\pm 95 \% \mathrm{CI}$ 

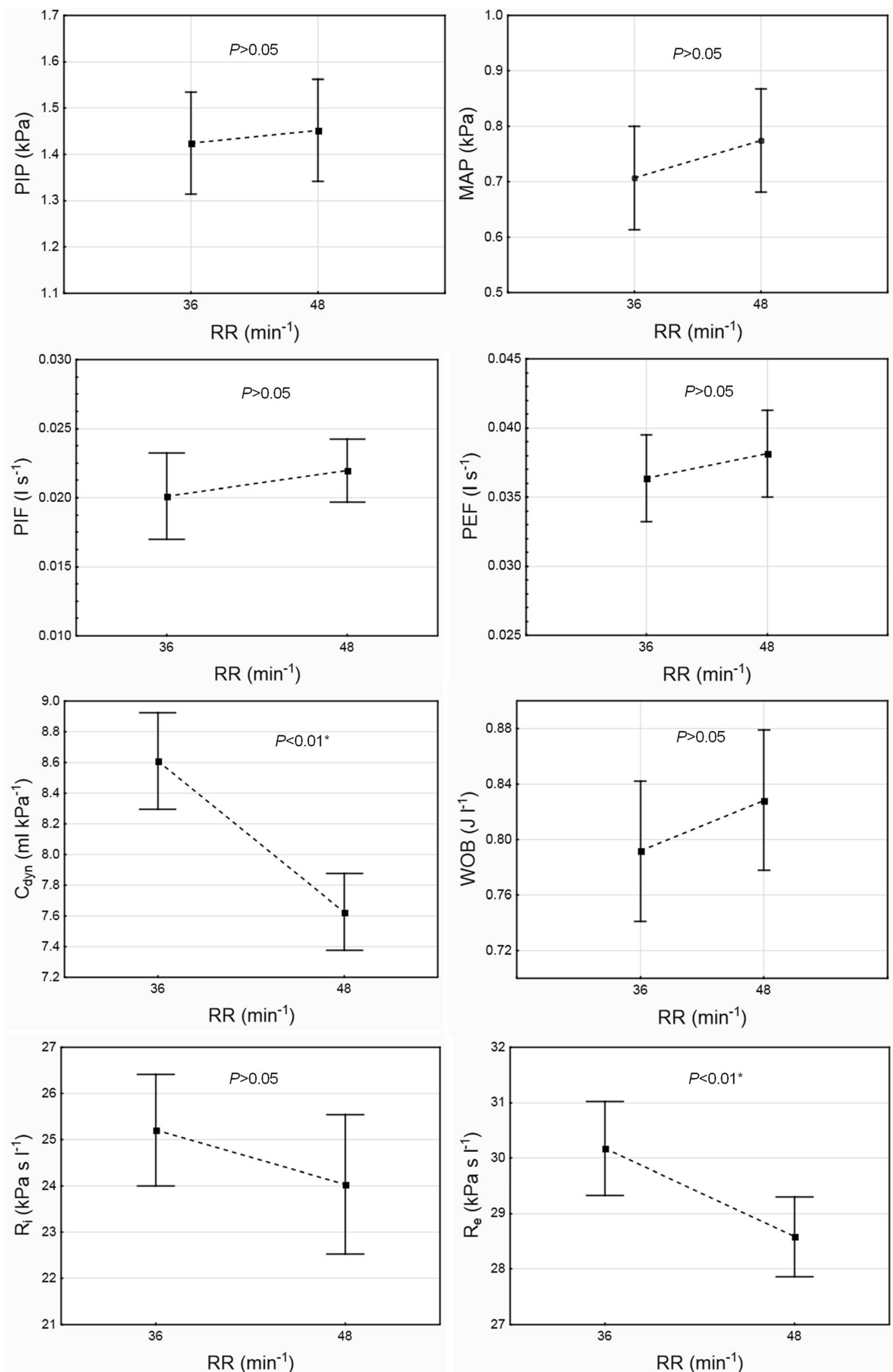

Fig. 5 The influence of the set respiratory rate (RR) on the infant's ventilation parameters: PIP, MAP, PIF, PEF, $C_{\mathrm{dyn}}, \mathrm{WOB}, R_{\mathrm{i}}$, and $R_{\mathrm{e}}(P<0.05,1-\beta=$ 0.83 ). The data are mean $\pm 95 \%$ CI 

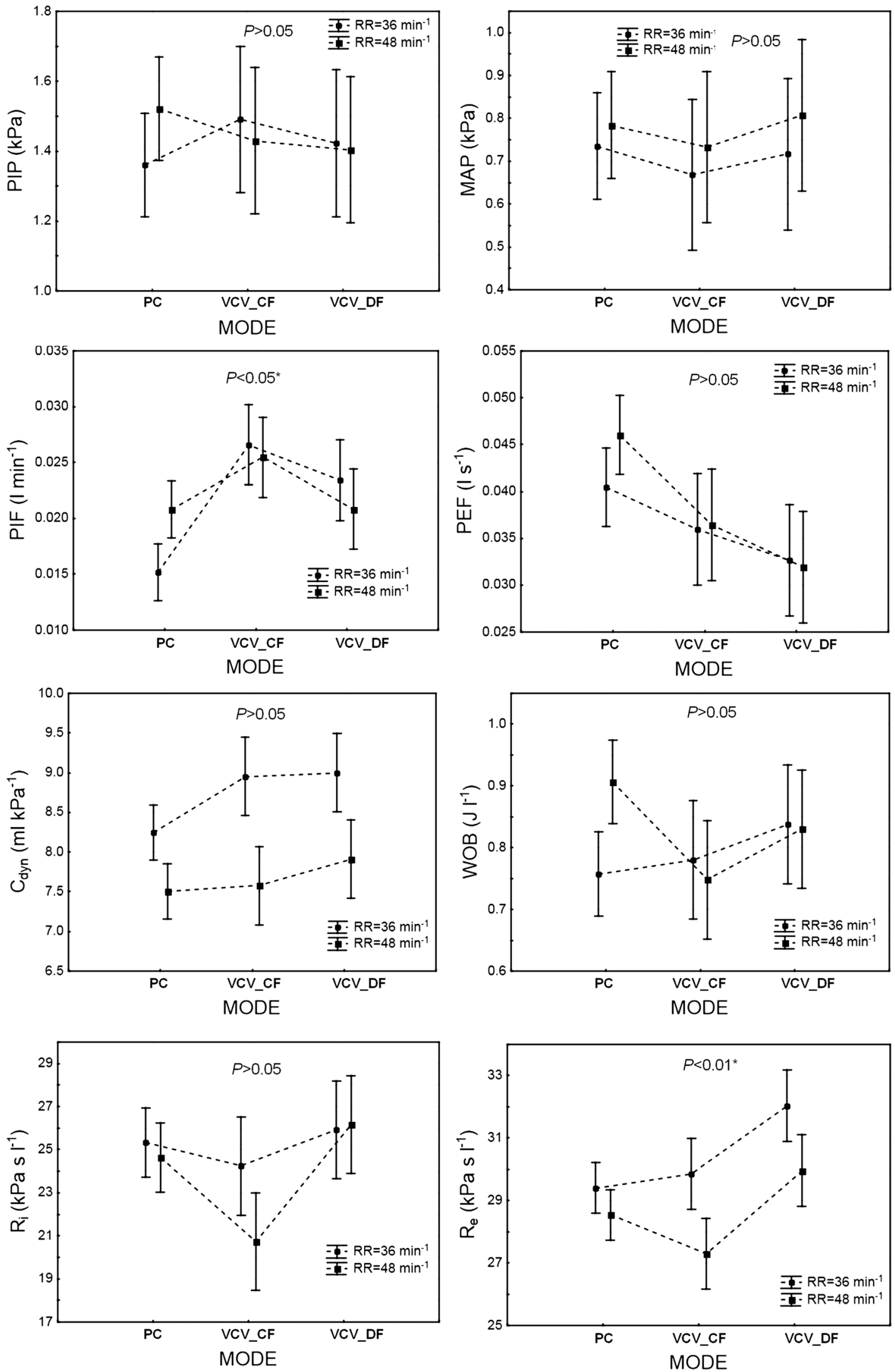

Fig. 6 The infant's ventilation parameters: PIP, MAP, PIF, PEF, $C_{\mathrm{dyn}}, \mathrm{WOB}, R_{\mathrm{i}}$, and $R_{\mathrm{e}}$, depending on ventilation $\mathrm{MODE}\left(\mathrm{PC}, \mathrm{VCV} \mathrm{CF}_{\mathrm{DC}}, \mathrm{VCV}_{\mathrm{DF}}\right)$ and respiratory rate $\mathrm{RR}\left(36,48 \mathrm{~min}^{-1}\right) . \mathrm{PC}=\mathrm{PCV}$. The data are mean $\pm 95 \% \mathrm{CI}$ 
STRATEGY, RR, PEEP) did not influence the output parameters of ventilation.

Finally, there were no significant differences among the minute ventilations $\left(\mathrm{MV}_{\mathrm{V}}\right)$ produced by the ventilator in PCV, $\mathrm{VCV}_{\mathrm{CF}}$, and $\mathrm{VCV}_{\mathrm{DF}}$ (Fig. 8). This shows that the study assumption was fulfilled $\left(\mathrm{MV}_{\mathrm{V}}=\right.$ const $)$. Wilcoxon's tests indicated that the difference between minute ventilation delivered by the ventilator $\left(\mathrm{MV}_{\mathrm{V}}\right)$ and that measured at the patient airway $\left(\mathrm{MV}_{\mathrm{T}}\right)$ was insignificant $(P>0.05)$.

On the other hand, a significant difference between the examined ventilation modes was observed for the minute ventilation $\left(\mathrm{MV}_{\mathrm{T}}\right)$ delivered to patient airways. The PCV (compared to $\mathrm{VCV}_{\mathrm{CF}}$ and $\mathrm{VCV}_{\mathrm{DF}}$ ventilation modes) enabled delivery of a significantly higher $(P<0.01 ; 1-\beta=0.99)$ minute ventilation to the patient airway $\left(\mathrm{MV}_{\mathrm{T}}\right)$ (Fig. 8), whereas the PIP, MAP, and WOB values did not differ statistically between modes.

\section{Discussion}

Ventilation therapy of preterm infants is aimed at reducing lung injury and avoiding BPD [20]. The latest clinical reports indicate that lung protective ventilation consists of limiting excessive expansion of the lung, applying PEEP, and using permissive hypercapnia [5, 7].

The higher risk of ventilator-induced lung injury in preterm infants compared to full-term infants is due to an insufficient amount of surfactant (or its inactivation) and lung inhomogeneity [6]. This impairs normal breathing and makes mechanical ventilation difficult in preterm infants $[1,11,17]$. Even though antenatal steroids and natural or synthetic surfactant administration after birth can increase lung compliance, it still remains comparable to circuit compliance [16]. The problem of the circuit compliance is extremely important when applying permissive hypercapnia as a lung protective ventilation method in preterm infants, due to the necessity of keeping the $\mathrm{P}_{\mathrm{a}} \mathrm{CO}_{2}$ level in the safe range $[1,15,27]$.

The difference between the tidal volume set on a ventilator and the actual tidal volume delivered to the patient is the dead space created by the circuit compliance. This can be a surprisingly large value in relation to patient's respiratory system compliance. It means that accurate compensation for the circuit compliance is necessary [9], or optionally, the influence of the circuit compliance on flow measurement should be accounted for in some way [3, 18]. Most modern ventilators are equipped with special algorithms for circuit compliance compensation. They incorporate the contribution of circuit compliance to calculated expired tidal volume, utilizing circuit compliance determined by a pre-use self-test and actual measurement of pressure changes in the circuit. However, there are some crucial points in the compensation procedure $[3,9,15,18]$, which make the procedure ineffective in some conditions. These points are as follows: (1) ventilator circuit layout, its length and shape during pre-use self-test [9]; (2) the placement of flow sensors in the ventilator circuit, which influences the accuracy of tidal volume delivered to the patient [3, 18]; (3) the influence of heaters, humidifiers, water traps, and other equipment of the ventilator circuit [3]; and finally, (4) successive ventilation modes of the ventilator can differ in effectiveness of compensation [15].

As was demonstrated by Glenski et al. [9], to determine the correct circuit compliance and to entirely compensate for the dead space created by it when ventilating an infant weighing less than $10 \mathrm{~kg}$, it is important to do a self-test with a circuit expanded as it is during patient ventilation. The reason for this is that the compliance of the expanded circuit is significantly higher than the compliance of a nonexpanded circuit. If the pre-use self-test is done with a nonexpanded circuit, the tidal volume displayed on the ventilator monitor can significantly overestimate the tidal volume delivered to the infant.

Then, most ventilators determine the expiratory tidal volume from the flow measured close to the expiratory valve (in-ventilator). Only a few ventilators (e.g., Hamilton Medical Galileo Ventilator) [18] calculate expiratory tidal volume from flow measured at the patient airway (between the Y-piece and the endotracheal tube); this allows them to avoid the influence of circuit compliance on flow and expiratory tidal volume. In this study, expiratory tidal volume was calculated from flow measurements made by the NICO sensor which was placed close to the patient airway between the Y-piece and the hybrid infant respiratory system (the physical part of the simulator, i.e., a cylinder with a piston).

Besides, it should be remembered that other circumstances or devices can influence the variation in ventilator circuit setup, such as heaters, humidifiers, water traps, in-line suction devices, condensation in the circuit, etc. In such a case, the expiratory $V_{\mathrm{T}}$ must be determined by pneumotachometer or other device (e.g., NICO monitor) so that the gas flow can be measured close to the patient airway, eliminating the problem with circuit compliance [3].

The simulations carried out indicate that, during ventilation of a preterm infant with respiratory system compliance close to circuit compliance, a ventilation method, ventilation strategy, and the recommended levels of $\mathrm{P}_{\mathrm{a}} \mathrm{CO}_{2}$ should be chosen very carefully, due to their influence on obtained ventilation parameters and patient safety. It appeared that pressurecontrolled ventilation is more effective than volumecontrolled ventilation in reaching the targeted tidal volume and minute ventilation. This means that, under PCV, the required minute ventilation can be obtained more easily, with lower levels of PIP, MAP, and WOB. Thus, PCV of preterm 

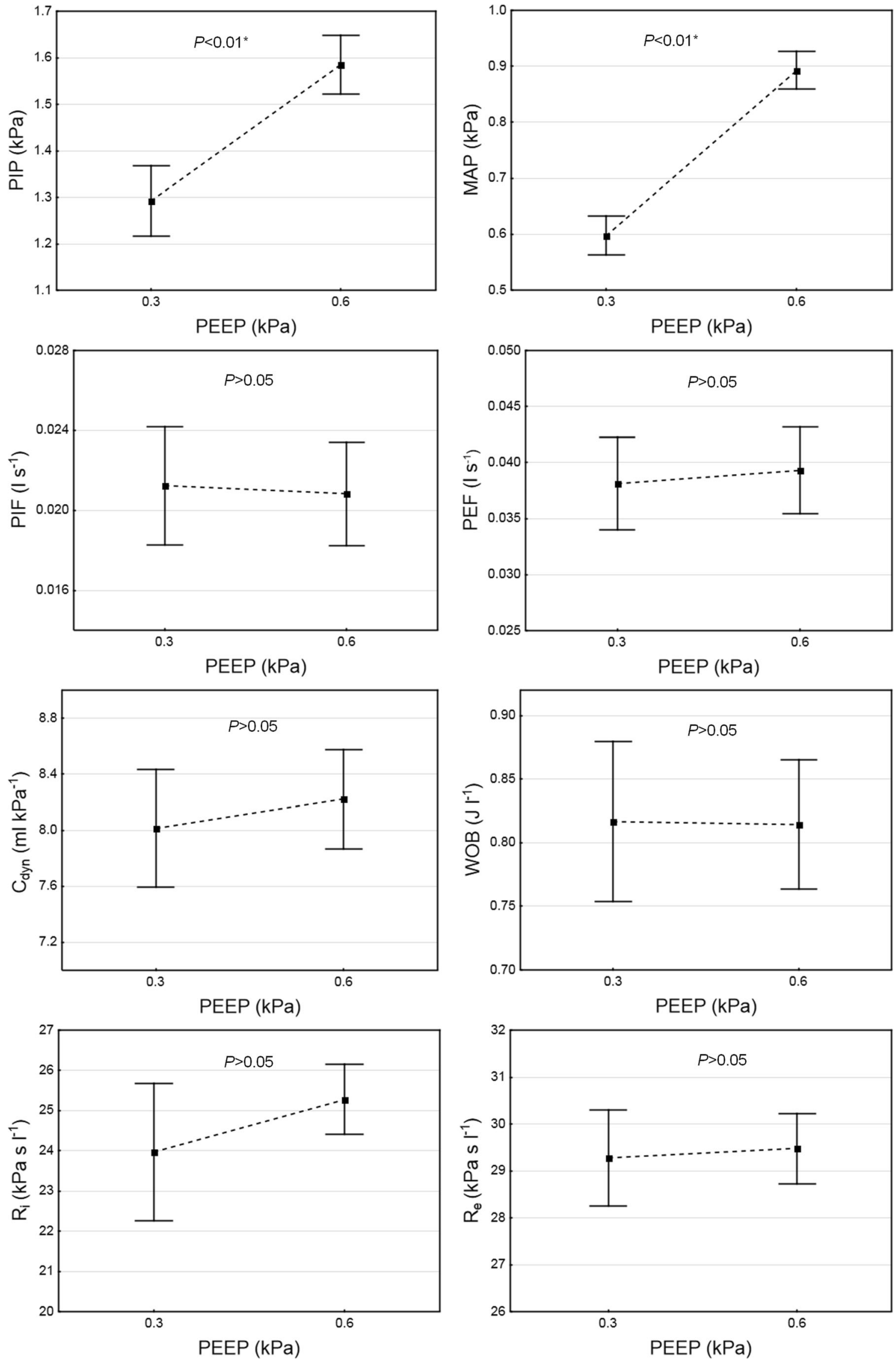
Fig. 7 The influence of positive end-expiratory pressure (PEEP) on the infant's ventilation parameters: PIP, MAP, PIF, PEF, $C_{\text {dyn }}$, WOB, $R_{\mathrm{i}}$, and $R_{\mathrm{e}}(P<0.01,1-\beta=0.99)$. The data are mean $\pm 95 \%$ CI

infants with very low respiratory system compliance seems to be more "lung protective" than VCV. This agrees with data on ventilation of preterm infants in the literature [1, 5, 7]. For example, in the Masselli et al. paper [15], PCV and VCV were compared to determine which is more effective in compensating for breathing circuit compressible volume. This study
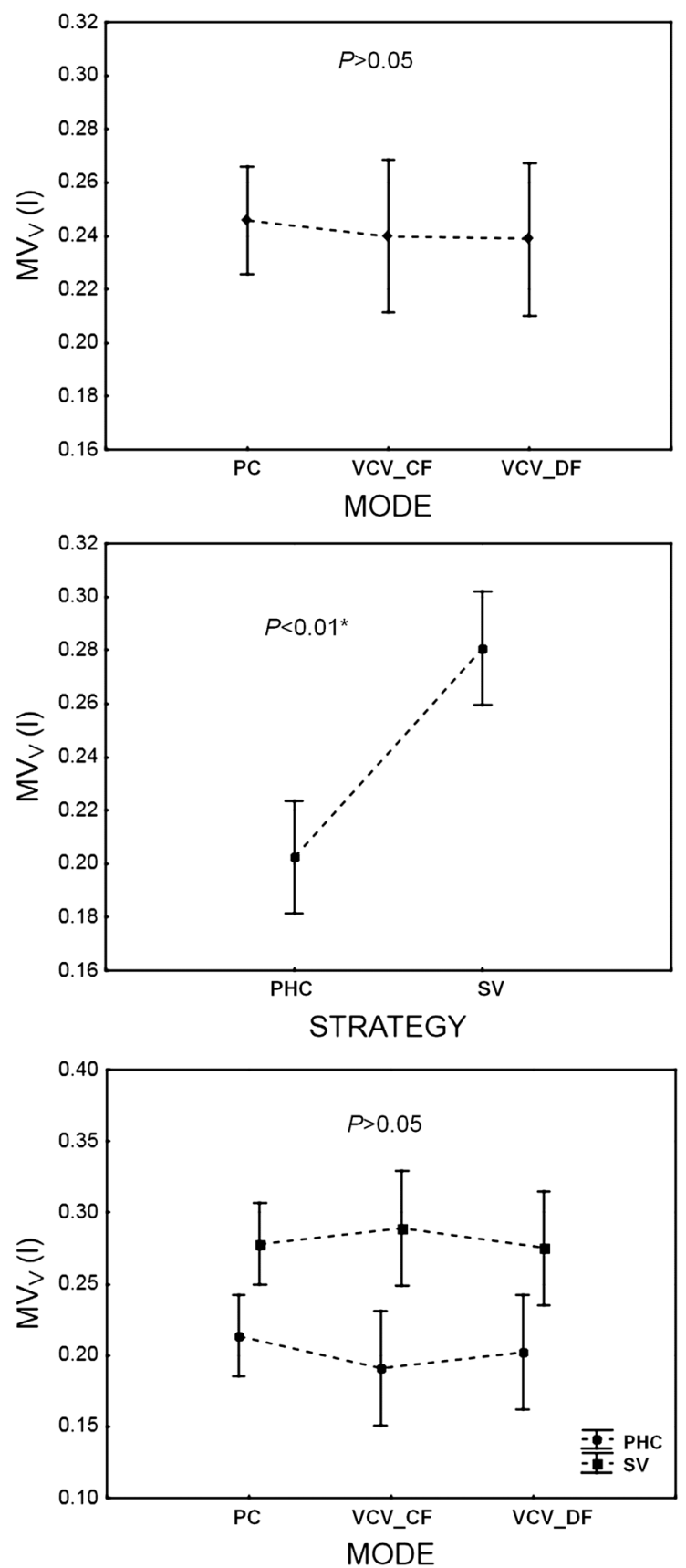

showed that the PCV resulted in a more reliable compensation of dead space created by circuit compliance. Similarly, our results indicated that tidal volumes set on the ventilator were closer to those actually delivered to the patient during PCV.

The study results also show that permissive hypercapnia is more advantageous than standard ventilation, because $\mathrm{PHC}$ was connected with lower levels of PIP, PIF, PEF, and WOB. There is a lower risk of barotrauma with the PHC strategy. Additionally, PHC improves tissue oxygenation by promoting the dissociation of oxygen from hemoglobin [4].
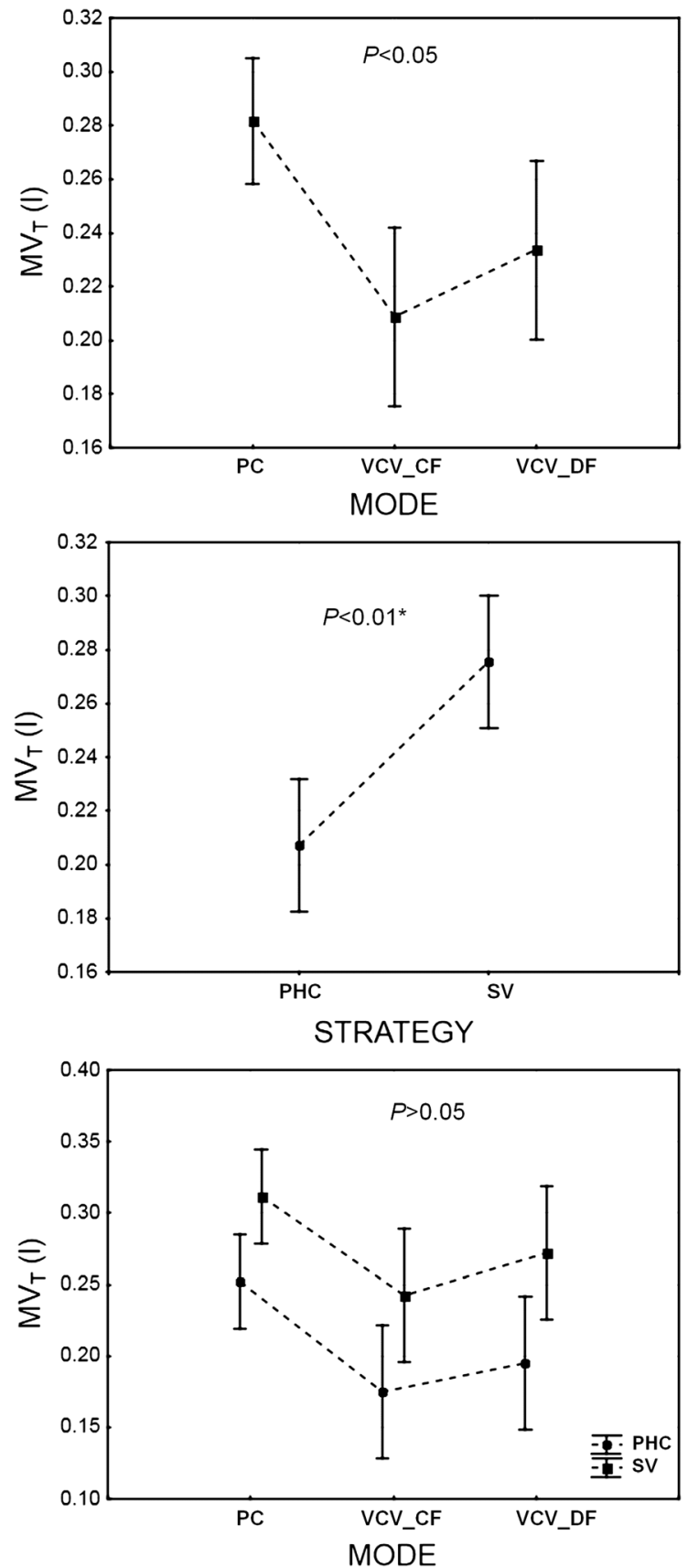

Fig. 8 Minute ventilation set on the ventilator $\left(\mathrm{MV}_{\mathrm{V}}\right)(\mathrm{a})$ and delivered to patient airways $\left(\mathrm{MV}_{\mathrm{T}}\right)(\mathrm{b})$ depending on ventilation mode $(\mathrm{PC}, \mathrm{VCV}$ $\mathrm{VCV}_{\mathrm{DF}}$ ) and ventilation strategy - permissive hypercapnia (PHC) versus normocapnia (SV). PC = PCV. The data are mean $\pm 95 \% \mathrm{CI}$ 
Due to its protective function [24, 27], permissive hypercapnia is more and more popular in clinical use [21,30]. A study from several years ago by van Kaam et al. [30] in 173 European neonatal intensive care units indicated that a strategy involving permissive hypercapnia was applied in $30 \%$ of patients. The Mu et al. survey from a few years before indicated that $70 \%$ of neonatologists from the USA were also using permissive hypercapnia [21].

An abnormal increase in $\mathrm{P}_{\mathrm{a}} \mathrm{CO}_{2}$, if not followed by metabolic compensation, decreases $\mathrm{pH}$ and leads to respiratory acidosis $\left(\mathrm{P}_{\mathrm{a}} \mathrm{CO}_{2}>45 \mathrm{mmHg}(6 \mathrm{kPa})\right.$ and $\left.\mathrm{pH}<7.35\right)$. While a $\mathrm{pH}$ range of 7.35-7.45 reflects physiologically normal values, the "clinical" range that is targeted for care may differ, e.g. the range of 7.25-7.35 may be accepted during ventilatory support under PHC $[2,28]$. European [28], US [10, 21], and Canadian [25] studies indicate that a $\mathrm{P}_{\mathrm{a}} \mathrm{CO}_{2}$ range of 45-65 (70) $\mathrm{mmHg}(6-8.7(9.3) \mathrm{kPa})$ is allowed under $\mathrm{PHC}$ as long as $\mathrm{pH}$ is $>7.25$ and oxygen saturation is $80-93 \%[10,25,28]$. PHC with $\mathrm{pH}>7.25$ has not been shown to increase the incidence of multiorgan failure or mortality. However, if circulatory system failure accompanies respiratory acidosis, it can lead to metabolic acidosis $\left(\mathrm{HCO}_{3}<20 \mathrm{mmol} / \mathrm{l}\right.$ and $\left.\mathrm{pH}<7.35\right)$ and the $\mathrm{pH}$ decreases as a result of hyperlactatemia and alkali deficiency. As a compensation for acidosis, pulmonary vasoconstriction with risk of persistent pulmonary hypertension, saturation decrease, and WOB increase can occur. As a consequence, central nervous system (CNS) damage, multiorgan failure, and coagulation disorders are observed in some of the patients $[2,10,28,30]$.

Measurement of $\mathrm{CO}_{2}$ is a fundamental evaluation in a neonatal intensive care unit (NICU), as both low and high values can impact neonatal morbidity and mortality [2]. The most accurate method to determine $\mathrm{P}_{\mathrm{a}} \mathrm{CO}_{2}$ level is blood gasometry (as well as measuring $\mathrm{pH}$ ). End-tidal $\mathrm{CO}_{2}$ monitoring or transcutaneous $\mathrm{CO}_{2}\left(\mathrm{tcCO}_{2}\right)$ measurements enable the continuous noninvasive measurement of $\mathrm{CO}_{2}$ values $[2,13]$. The former, based on the $\mathrm{CO}_{2}$ partial pressure measurement at the end of exhalation $\left(\mathrm{P}_{\mathrm{et}} \mathrm{CO}_{2}\right)$, facilitates the control of $\mathrm{CO}_{2}$ values within the safe range during conventional ventilation under PHC [13]. However, this method is not reliable or accurate enough in some cases, for example, in the case of a leak due to an uncuffed tube, if the side-stream method is used, or under HFV. More recently, the latter method, based on $\mathrm{CO}_{2}$ diffusion by body tissue and skin, has been shown to provide more accuracy. Additionally, it helps to reduce the frequency of blood sampling in extremely preterm infants [2].

The adverse effects of PHC remain unclear. A significant increase in CNS hemorrhage episodes in children treated with PHC has not been observed so far $[10,28]$. However, hypercapnia causes vasodilation and a rise in intracranial flow, increasing the risk of intraventricular hemorrhage. For this reason, PHC should not to be applied in patients with cerebral edema and elevated intracranial pressure [10, 27]. Nonetheless, in most patients, mild hypercapnia seems to be safer than lung damage (which may occur at higher pressures and volumes during SV) or hypocapnia (leading to periventricular leukomalacia and distant neurologic deficits) [27].

To summarize, on the basis of the study results, we suggest ventilating preterm infants with respiratory system compliance close to circuit compliance using PCV rather than VCV, under hypercapnia rather than normocapnia conditions. Moreover, we recommend the lowest possible RR settings. However, the tidal volume delivered to the patient should be carefully controlled using some device like a pneumotachograph or special ventilator calculating expired tidal volume from flow measured at patient airways (not at the expiratory valve).

\section{Conclusions}

Considering the effectiveness of mechanical ventilation, energetic cost of respiratory support and patient safety, the most beneficial technique appears to be pressure control ventilation under permissive hypercapnia conditions, because it allows the largest minute ventilation at the lowest pressure levels in the circuit (PIP and MAP) and it requires the lowest WOB.

\section{Compliance with ethical standards}

Conflict of interest The authors declare that they have no conflict of interest.

\section{References}

1. Brown MK, DiBlasi KM (2011) Mechanical ventilation in the premature neonate. Respir Care 56:1298-1313

2. Bruschettini M, Romantsik O, Zappettini S, Ramenghi LA, Calevo MG (2016) Transcutaneous carbon dioxide monitoring for the prevention of neonatal morbidity and mortality. Cochrane Database Syst Rev (2, Art. No.: CD011494). https://doi.org/10.1002/ 14651858.CD011494.pub2

3. Cannon ML, Cornell J, Tripp-Hamel DS et al (2000) Tidal volumes for ventilated infants should be determined with a pneumotachometer placed at the endotracheal tube. Am J Respir Crit Care Med. https://doi.org/10.1111/pan.13332

4. Dickson EW, Nilles SJ, Lynch WR, Ludwig PS, Armstrong JG (2007) Permissive hypercapnia promotes the dissociation of oxygen from hemoglobin. Ann Emerg Med 50:S6-S18

5. Donn SM, Sinha SK (2006) Minimising ventilator induced lung injury in preterm infants. Arc Dis Child Fetal Neonatal Ed. https://doi.org/10.1136/adc.2005.082271

6. Edibam C (2000) Ventilator-induced lung injury and implications for clinical management. Crit Care Resusc 2:269-277

7. Garcia-Fernandez J, Castro L, Belda FJ (2010) Ventilating the newborn and child. Curr Anaesth Crit Care 21:262-268 
8. Gien J, Kinsella JP (2011) Pathogenesis and treatment of bronchopulmonary dysplasia. Curr Opin Pediatr. https://doi.org/ 10.1097/MOP.0b013e328346577f

9. Glenski TA, Diehl C, Clopton RG, Friesen RH, Lerman J (2017) Breathing circuit compliance and accuracy of displayed tidal volume during pressure-controlled ventilation of infants: a quality improvement project. Pediatr Anesth 27:936-941

10. Guidry CA, Hranjec T, Bradley M et al (2012) Permissive hypercapnia in the management of congenital diaphragmatic hernia: our institutional experience. J Am Coll Surg. https://doi.org/10.1016/j. jamcollsurg.2011.12.036

11. Hjalmarson O, Sandberg K (2002) Abnormal lung function in healthy preterm infants. Am J Respir Crit Care Med. https://doi. org $/ 10.1164 / \mathrm{rccm} 2107093$

12. Kessel I, Waisman D, Barnet-Grinnes O, Ben Ari TZ, Rotschild A (2010) Benefits of high frequency oscillatory ventilation for premature infants. IMAJ 12:144-149

13. Kugelman A, Golan A, Riskin A et al (2016) Continuous capnography in ventilated neonates: a randomized, multicenter study. J Pediatr 168:56-61. https://doi.org/10.1016/j.jpeds.2015. 09.051

14. López ES, Rodríguez EM, Navarro CR et al (2011) Initial respiratory management in preterm infants and bronchopulmonary dysplasia. Clin Sci 66:823-827

15. Masseli GMP, Sciuto SA, Cappa P (2006) Circuit compliance compensation in lung protective ventilation. 2006 International Conference of the IEEE EMBAS. https://doi.org/10.1109/IEMBS.2006.260066.

16. McEvoy C, Schilling D, Peters D et al (2010) Respiratory compliance in preterm infants after a single rescue course of antenatal steroids: a randomized controlled trial. Am J Obstet Gynecol. https://doi.org/10.1016/j.ajog.2010.01.038

17. Mello RR, Silva KS, Costa AM, Ramos JRM (2015) Longitudinal assessment of the lung mechanics of very low birth weight infant. Sao Paulo Med J. https://doi.org/10.1590/1516-3180. 201400101812

18. Miller SL, Wysocki M (2005) Tidal volumes for ventilated patients should be determined at the endotracheal tube. HAMILTON MEDICAL Intelligent Ventilation. White Paper 689217/00 (C) HAMILTON MEDICAL AG. https://www.hamilton-medical. com. Accessed 15 Oct 2018.

19. Monte LF, Silva Filho LV, Miyoshi MH et al (2005) Bronchopulmonary dysplasia. J Pediatr 81:99-110

20. Moss TJM (2005) The respiratory consequences of preterm birth. Proc Aust Physiol Soc 36:23-28

21. Mu TS, Sawyer TL, Jordan CP et al (2011) Permissive hypercapnia practices among neonatologists in the United States: results of a national survey. JNPM 4:111-117

22. Onland W, Debray TP, Laughon MM, Miedema M, Cools F, Askie LM, Asselin JM, Calvert SA, Courtney SE, Dani C, Durand DJ, Marlow N, Peacock JL, Pillow JJ, Soll RF, Thome UH, Truffert P, Schreiber MD, van Reempts P, Vendettuoli V, Vento G, van Kaam AH, Moons KG, Offringa M (2013) Clinical prediction models for bronchopulmonary dysplasia: a systematic review and external validation study. BMC Pediatr 13:1-20. https://doi.org/10.1186/14712431-13-207

23. Ou X, Glasier CM, Ramakrishnaiah RH et al (2014) Diffusion tensor imaging in extremely low birth weight infants managed with hypercapnic vs. normocapnic ventilation. Pediatr Radiol. https:// doi.org/10.1007/s00247-014-2946-8

24. Ryu J, Haddad G, Carlo WA (2012) Clinical effectiveness and safety of permissive hypercapnia. Clin Perinatol 39:603-612

25. Sant'Anna GM, Keszler M (2012) Developing a neonatal unit ventilation protocol for the preterm baby. Early Hum Dev 88:925-929. https://doi.org/10.1016/j.earlhumdev.2012.09.010

26. Stankiewicz B, Pałko KJ, Darowski M, Zieliński K, Kozarski M (2017) A new infant hybrid respiratory simulator: preliminary evaluation based on clinical data. MBEC 55:1937-1948. https:// doi.org/10.1007/s11517-017-1635-9

27. Thome UH, Ambalavanan N (2009) Permissive hypercapnia to decrease lung injury in ventilated preterm neonates. Semin Fetal Neonatal Med. https://doi.org/10.1016/j.siny.2008.08.005

28. Thome UH, Genzel-Boroviczeny O, Bohnhorst B, Schmid M, Fuchs H, Rohde O, Avenarius S, Topf HG, Zimmermann A, Faas D, Timme K, Kleinlein B, Buxmann H, Schenk W, Segerer H, Teig N, Gebauer C, Hentschel R, Heckmann M, Schlösser R, Peters J, Rossi R, Rascher W, Böttger R, Seidenberg J, Hansen G, Zernickel M, Alzen G, Dreyhaupt J, Muche R, Hummler HD, PHELBI Study Group (2015) Permissive hypercapnia in extremely low birth weight infants (PHELBI): a randomised controlled multicentre trial. Lancet Respir Med 3(7):534-543. https://doi.org/10.1016/S22132600(15)00204-0

29. Trembath A, Laughon M (2012) Predictors of bronchopulmonary dysplasia. Clin Perinatol. https://doi.org/10.1016/j.clp.2012.06.014

30. van Kaam AH, De Jaegere AP, Rimensberger PC (2013) Incidence of hypo- and hyper-capnia in a cross-sectional European cohort of ventilated newborn infants. Arch Dis Child Fetal Neonatal 98: F323-F326

Publisher's note Springer Nature remains neutral with regard to jurisdictional claims in published maps and institutional affiliations.

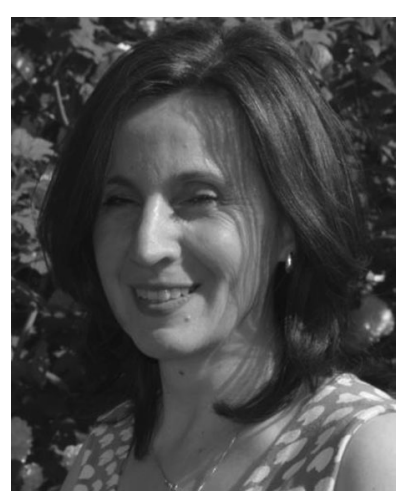

Barbara Stankiewicz, $\mathrm{PhD}$, is a physicist with 20 years of experience in biomedical engineering. Her current research interests are focused on pediatric respiratory system modeling and assistance.

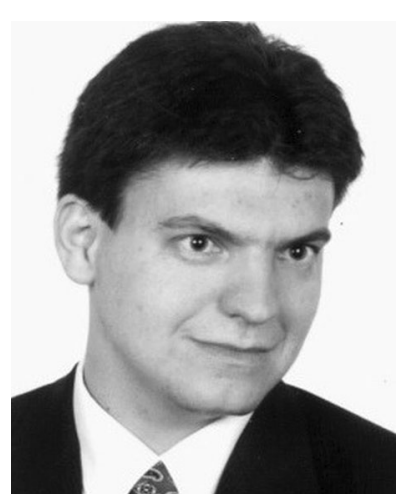

Krzysztof J. Pałko, $\mathrm{PhD}$, is a biomedical engineer with 15 years of experience in modeling and measurements with varied applications to biomedical systems development for the cardiorespiratory system. 


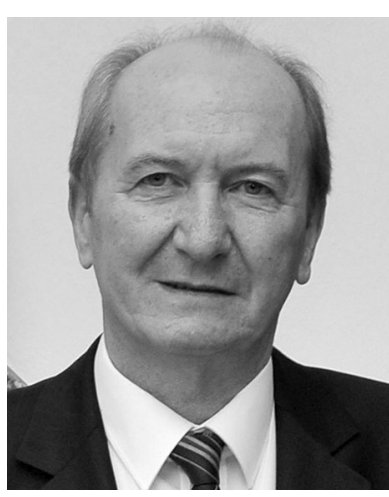

Marek Darowski , Prof, $\mathrm{PhD}$, is an engineer with more than 40 years of experience in respiratory and circulatory systems modeling and assistance, developing new therapy methods and devices.

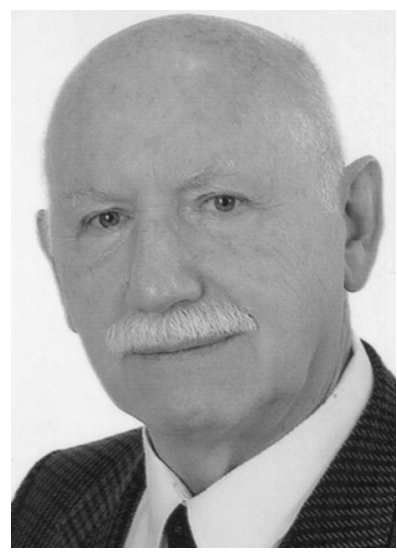

Maciej Kozarski , $\mathrm{PhD}$, is an engineer with more than 40 years of experience in respiratory and circulatory systems modeling and assistance and an author of many articles and patents in the field. 